\title{
Proteinuria in Nephrotic Syndrome: Mechanistic and Clinical Considerations in Optimizing Management
}

Guest Editors

James A. Tumlin, Chattanooga, TN

Kirk N. Campbell, New York, NY 


\section{Sponsor Note}

This publication is based on discussions at a roundtable meeting supported by a grant from Mallinckrodt Pharmaceuticals. Presentations and discussions were developed solely by the participants, without grantor input.

\section{Disclosure Statement}

K.N.C. and J.A.T. received honoraria from IQVIA (formerly QuintilesIMS) for their participation in a roundtable meeting supported by a grant from Mallinckrodt Pharmaceuticals. J.A.T. is a consultant for Mallinckrodt and has received previous research funding. K.N.C. has served as a consultant for Mallinckrodt and serves on the Medical Advisory Board of the National Kidney Foundation of Greater New York.

\section{S. Karger}

Medical and Scientific Publishers Basel · Freiburg · Paris · London . New York $\cdot$ Chennai $\cdot$ New Delhi . Bangkok $\cdot$ Beijing $\cdot$ Shanghai $\cdot$ Tokyo . Kuala Lumpur $\cdot$ Singapore $\cdot$ Sydney

\section{Disclaimer}

The statements, opinions and data contained in this publication are solely those of the individual authors and contributors and not of the publisher and the editor(s). The appearance of advertisements in the journal is not a warranty, endorsement, or approval of the products or services advertised or of their effectiveness, quality or safety. The publisher and the editor(s) disclaim responsibility for any injury to persons or property resulting from any ideas, methods, instructions or products referred to in the content or advertisements.

Drug Dosage

The authors and the publisher have exerted every effort to ensure that drug selection and dosage set forth in this text are in accord with current recommendations and practice at the time of publication. However, in view of ongoing research, changes in government regulations, and the constant flow of information relating to drug therapy and drug reactions, the reader is urged to check the package insert for each drug for any change in indications and dosage and for added warnings and precautions. This is particularly important when the recommended agent is a new and/or infrequently employed drug.
All rights reserved.

No part of this publication may be translated into other languages, reproduced or utilized in any form or by any means, electronic or mechanical, including photocopying, recording microcopying, or by any information storage and retrieval system, without permission in writing from the publisher or, in the case of photocopying, direct payment of a specified fee to the Copyright Clearance Center (see 'General Information').

(C) Copyright 2018 by S. Karger AG,

P.O. Box, CH-4009 Basel (Switzerland)

Printed on acid-free and non-aging paper (ISO 9706)

ISBN 978-3-318-06210-6

e-ISBN 978-3-318-06211-3

\section{KARGER}




\section{Contents}

Introduction

1 Proteinuria in Nephrotic Syndrome: Mechanistic and Clinical Considerations in Optimizing Management

Tumlin, J.A. (Chattanooga, TN); Campbell, K.N. (New York, NY)

Review Articles

3 A Review of Podocyte Biology

Garg, P. (Ann Arbor, MI)

14 Protecting Podocytes: A Key Target for Therapy of Focal Segmental Glomerulosclerosis

Campbell, K.N. (New York, NY); Tumlin, J.A. (Chattanooga, TN)

30 Membranous Nephropathy: Approaches to Treatment

Bomback, A.S. (New York, NY); Fervenza, F.C. (Rochester, MN)

43 Immunoglobulin A Nephropathy: Advances in Understanding of Pathogenesis and Treatment

Lafayette, R.A. (Stanford, CA); Kelepouris, E. (Philadelphia, PA) 
